University of Nebraska - Lincoln

DigitalCommons@University of Nebraska - Lincoln

Faculty Publications: Department of Teaching, Department of Teaching, Learning and Teacher Learning and Teacher Education

Education

2011

\title{
Evolution and personal religious belief: Christian university biology-related majors' search for reconciliation
}

\author{
Mark Winslow \\ Southern Nazarene University, mwinslow@snu.edu \\ John Staver \\ Purdue University, jstaver@purdue.edu \\ Lawrence C. Scharmann \\ University of Nebraska-Lincoln, Ischarmann2@unl.edu
}

Follow this and additional works at: https://digitalcommons.unl.edu/teachlearnfacpub

Part of the Biology Commons, Curriculum and Instruction Commons, and the Teacher Education and Professional Development Commons

Winslow, Mark; Staver, John; and Scharmann, Lawrence C., "Evolution and personal religious belief: Christian university biology-related majors' search for reconciliation" (2011). Faculty Publications:

Department of Teaching, Learning and Teacher Education. 384.

https://digitalcommons.unl.edu/teachlearnfacpub/384

This Article is brought to you for free and open access by the Department of Teaching, Learning and Teacher Education at DigitalCommons@University of Nebraska - Lincoln. It has been accepted for inclusion in Faculty Publications: Department of Teaching, Learning and Teacher Education by an authorized administrator of DigitalCommons@University of Nebraska - Lincoln. 


\title{
Evolution and Personal Religious Belief: Christian University Biology-Related Majors' Search for Reconciliation
}

\author{
Mark W. Winslow, ${ }^{1}$ John R. Staver, ${ }^{2}$ and \\ Lawrence C. Scharmann ${ }^{3}$
}

\begin{abstract}
1 Southern Nazarene University, Bethany, Oklahoma 73008
2 Center for Research and Engagement in Science and Mathematics Education (CRESME), Purdue University, West Lafayette, Indiana 47907

3 School of Teacher Education, College of Education, Florida State University, Tallahassee, Florida 32306
\end{abstract}

Correspondence: M.W.Winslow; email mwinslow@snu.edu

\begin{abstract}
The goal of this study was to explore Christian biology-related majors' perceptions of conflicts between evolution and their religious beliefs. This naturalistic study utilized a case study design of 15 undergraduate biology-related majors at or recent biology-related graduates from a mid-western Christian university. The broad sources of data were interviews, course documents, and observations. Outcomes indicate that most participants were raised to believe in creationism, but came to accept evolution through evaluating evidence for evolution, negotiating the literalness of Genesis, recognizing evolution as a non-salvation issue, and observing professors as Christian role models who accept evolution. This study lends heuristic insight to researchers and educators seeking to understand the complex processes by which Christian biology-related majors approach learning about evolution.
\end{abstract}

Keywords: evolution; religious beliefs; Christian

Published in Journal of Research in Science Teaching 48:9 (2011), pp 1026-1049.

DOI 10.1002/tea.20417

Copyright (C) 2011 Wiley Periodicals, Inc. Used by permission.

Submitted 3 August 2010; accepted 24 March 2011; published 29 April 2011. 
The scientific and religious dialectical debate regarding evolution 1 continues unabated in the United States. "Creationism," the religious view that a supernatural deity has directly intervened to create the universe, has many forms-some of which seek to discredit biological evolution and foster distrust of evolutionary science among American Christians (Scott, 2009). Christian students who attend secular or religious universities that include the topic of evolution in the science curricula may experience dissonance with their interacting notions of evolution and creationism. This study explored the process through which Christian biology-related majors at a Christian university sought reconciliation between their understanding of evolution and personal religious beliefs.

A broad spectrum of beliefs exists within Christian versions of creationism (Scott, 2009). At one end of the creationism spectrum, "Young Earth Creationists" believe in the literal interpretation of Genesis, that the universe is 6,000-10,000 years old and that God created a multiplicity of living beings in 6 days. Another distinct group on the creationism spectrum is the Progressive Creationists, or "Old Earth Creationists,' who agree with currently accepted cosmological and geological theories, but reject basic tenets of biological evolution such as the dynamic view of speciation (Colburn \& Henriques, 2006; Scott, 2009). Progressive creationists believe that God, in a supernatural act, created plant and animal life at important junctures in history. Young Earth and Progressive creationists categorically reject evolution as descent with modification from a single common ancestor. The Intelligent Design (ID) movement has found traction as an activist form of creationism in churches and school boards (Kitzmiller vs. Dover Area School Board, 2005). Its advocates posit that certain biological structures have the appearance of intelligent design (Behe, 1996) and could not have come about by evolution.

Religious belief does not have to preclude acceptance of evolution. Theistic evolutionists believe that God works through the laws of nature in harmony with currently accepted theories of science. Colburn and Henriques (2006) broadly define theistic evolution as a "marriage of theism and evolution" (p. 435). Although many theistic evolutionists maintain that God "creates" through natural processes, the term "creationist" in this study applies only to Young Earth and Progressive creationists and Intelligent Design advocates opposed to the theory of evolution (Evans et al., 2010). 


\section{Belief, Understanding, and Acceptance of Evolution}

Science education research literature contains interventions to help students achieve an understanding of evolutionary theory. The conceptual change model uses a constructivist approach to recognize that the learning of new concepts hinges upon or may be impeded by students' existing conceptions (Wandersee, Mintzes, \& Novak, 1994) and suggest methods to foster change in the students' conceptions (Bishop \& Anderson, 1990; Demastes, Settlage, \& Good, 1995). More recently, science educators have focused on teaching the nature of science to promote an acceptance of evolutionary theory (Bybee, 2004; Dagher \& BouJaoude, 1997; National Academy of Sciences [NAS], 1998; Verhey, 2005). Providing students with an understanding of the nature of science allows them to demarcate the boundaries of and distinguish between knowledge claims made by science and religion.

One question that emerges from science education literature is, "What is the goal for evolution instruction?" Three terms are found most often within studies that articulate the goal of evolution instruction: belief, understanding, and acceptance. A number of studies focus on investigating the factors that affect students' "belief in evolution," as if belief is the goal of instruction (e.g., Bishop \& Anderson, 1990; Lord \& Marino, 1993). For instance, McKeachie, Lin, and Strayer (2002) asked, "How does a biology course affect student beliefs about evolution?” (p. 189).

Cobern (1994) argues that the primary goal of teaching evolutionary concepts is the understanding of evolution rather than a belief in evolution. However, Cobern stresses that belief should be "allowed a legitimate role in the science classroom" (p. 588) as personal beliefs can impede an understanding of evolution. Cobern associates belief with knowing that a concept is true or valid. Smith (1994) contends that Cobern's view is misguided in equating the acceptance of a concept with believing that it is so. Smith agrees that students' beliefs can significantly impact their learning of evolution, but writes, "The genuine scientist is bound by the rules of evidence and judges the validity of various claims on the basis of empirical evidence, not on the basis of his personal convictions, opinions, and beliefs" (p. 594). Scharmann (2005) also argues that the goal for biology education is not to make students believe in evolution. Rather, the goal is for students to "understand evolutionary theory to be the most powerful contemporary 
problem-solving tool at the disposal of the biologist [italics in original]" (p. 13).

Several studies have addressed the relationship between an acceptance and an understanding of evolution. A study of an undergraduate non-majors biology class showed that there is no relation between students' knowledge of evolution and their reported acceptance of it (Sinatra, Southerland, McConaughy, \& Demastes, 2003). Bishop and Anderson (1990) found that an improvement in college students' understanding of evolution "did not generally change their convictions about the truthfulness of the theory" (p. 426). In a study by Lord and Marino (1993), most of the three-quarters of the college students who said they thought evolution was true did not have an understanding of the mechanism behind it. Summarizing these studies, understanding does not necessitate an acceptance of evolution, nor is understanding required to accept evolution.

In a study of university students in an upper-level evolution course, Ingram and Nelson (2006) found that although constructivist instruction significantly increased acceptance of evolution, the acceptance or rejection of evolution did not have a significant influence on students' achievement in the course. Ingram and Nelson maintain that understanding enables but does not require an acceptance of evolution. Therefore "understanding evolution is more important than accepting evolution," and teachers should ask students to "strive for understanding prior to making decisions regarding acceptance of any theory" (Ingram \& Nelson, 2006, p. 20).

To summarize, many studies affirm the primary importance of understanding evolution while acknowledging the implicit goal of having students accept evolution as valid. However, nonscientific and religious beliefs can interfere with an understanding of evolution (Meadows, Doester, \& Jackson, 2000). Dagher and BouJaoude (1997) argue that rationality is not the only factor in students' synthesis of evolutionary theory and that prior ideas, beliefs, values and emotions form a set of interpretive categories through which new knowledge is incorporated. Hokayem and BouJaoude (2008) advocate for a better understanding of the relation between personal beliefs and perceptions of evolution through qualitative studies and suggest that religious beliefs "cannot be treated as misconceptions but have to be included as part of an individual's 'cultural milieu' that requires detailed description and analysis rather than modification" (p. 398). This 
study specifically explored the interaction of evolution and personal religious beliefs for Christian students learning about evolution. The implications are important for science education to further investigate the complex interaction of university students' religious beliefs with a nascent understanding of evolution, and how university students who seek to accommodate evolution in their worldview accord the salient factors that contribute to the decision-making process.

\section{Evolution and Personal Religious Beliefs}

Accommodation occurs when learners are confronted with evidence that conflicts with existing mental structures and subsequently adapt their schema to minimize the dissonance in a process of equilibration (Renner \& Stafford, 1979). The interaction of religious beliefs with learning about evolution can represent a crisis experience for Christian college students whose principal exposure to evolution has been through anti-evolutionist perspectives (Miller, 2003). Meadows et al. (2000) contend that persons whose religious beliefs are in apparent conflict with evolution may actively resist learning about evolution. Meadows et al. state, "These students do not fail to learn about evolution as teachers often think; instead, they actively choose not to learn about evolution" (p. 106). In this study, the researchers postulated that participants whose religious beliefs created dissonance with their learning about evolution would encounter several issues before accepting evolution, including: judging the credibility of evolution; a literal interpretation of Genesis; and theological implications of evolution. These issues, though not sequential or hierarchal, may represent components in the reconciliation process of accommodating evolution.

To accommodate evolution, the student must find the theory credible, or appearing to merit acceptance. This is a difficult step for students with creationist perspectives (Meadows et al., 2000). Many creationist activists seek to discredit evolution (Alters \& Alters, 2001; Scott, 2009; Williams, 2009). Judge Jones, in his ruling in Kitzmiller $v$. Dover Area School District (2005), observed that ID is "premised upon a false dichotomy, namely, that to the extent evolutionary theory is discredited, ID is confirmed" (p. 71). Another process in Christian university students' accommodation of evolution is coming to terms with

a viable interpretation of Genesis (Dutch, 2002). Creationist leaders 
(e.g., Ham, 1987) warn that a literary, rather than a literal interpretation, of Genesis is a dangerous, slippery slope that "undermine[s] the very foundation of Christianity" (MacArthur, 2001, p. 44). Creationist students exposed to such rhetoric may need to reexamine their beliefs about Genesis before accepting evolution.

Finally, creationist students who are considering evolution may need to deal with implications that evolution holds for their theology, including God's interventional role in creation. In response to the contingent nature of genetic mutations, Miller (1999) asks the rhetorical question: "Doesn't the very randomness of evolution rule out any notion of divine purpose?” (p. 233). Some Christians struggle with evolutionary mechanisms that appear devoid of divine guidance (O'Leary, 2003). Murphy (2002) writes that opposition to evolution by highly conservative Christians "can be understood as a reaction to the claims that the appearance. . . of life. . . requires no special divine creative acts-no interventions in the natural order" (p. 33). The critical issue in this study was whether the participants invoked scientific explanations for natural phenomena such as abiogenesis or instead leaned towards non-scientific assertions that God specially created first life in an act of divine intervention.

To summarize, for a creationist university student, a number of issues may require deliberation in order to accommodate evolution, including coming to terms with evolution's credibility, a non-literalist interpretation of Genesis, and some reconciliation of God's interventional role in nature. Full resolution on the issues may not be necessary and other factors may be present in the accommodation process, which was explored in this study. One cannot overstate that the aforementioned issues, with the exception of evolution's credibility, are not scientific. Still, each may be important in the "crucible" within creationist university students' minds that mediates the perceived dissonance between their acceptance of evolutionary theory and their personal religious beliefs, and therefore was explored in this study.

\section{Study Central Questions and Sub-Questions}

The central question that framed this study was: How do Christian biology-related majors at a Christian university reconcile evolution and 
their personal religious beliefs? Three sub-questions relevant to the central question were investigated:

- What factors influence participants' perspectives on evolution and creationism?

- What are participants' extant views on evolution and creationism?

- What aspects of evolutionary theory and personal religious beliefs create dissonance for participants?

\section{Methods}

This study utilized a socially constructed knowledge framework which maintains that individuals develop subjective interpretations of their experiences arising from their social interactions and their individual thinking (Creswell, 2003). The socially constructed knowledge claim was well suited to this study because of the research focus on participants' meaning making through personal experiences and how those constructions influenced reconciliation of perceived conflicts between evolution and personal religious beliefs.

Case study research focuses on holistic descriptions, in-depth analyses, and understanding of the investigated phenomenon (Merriam, 1998). This naturalistic research study utilized an instrumental case study design (Stake, 2000). The single case was a bounded system of undergraduate biology-related majors and recent biology-related graduates from a Christian liberal arts university. The typical site sampling strategy was used for this study, meaning, "the site is specifically selected because it is not in any major way atypical, extreme, deviant, or intensely unusual" (Patton, 1990, p. 173). While a diversity of approaches exists in addressing evolution issues at Christian universities (Alters \& Alters, 2001), no aspect of the study site suggested that it was atypical of higher education institutions committed to the teaching of evolution in non-opposition to religious belief. The site for this study was a Midwestern Christian university with an undergraduate enrollment of 1,200 students. The institution offers the usual variety of small university science programs including biology, chemistry, and physics degrees. 


\section{Participants}

The purposeful sampling method (Patton, 1990) was employed to select "information-rich" cases (participants) with significant relevance to the central question of the study. Participants were senior biologyrelated majors (biology, biology-chemistry, or biological science education) and recent graduates within the last 2 years who majored in biology-related science, and had completed an upper-level biology course on evolution entitled Origins, as described in the 2005-2007 university catalog:

A multi-disciplinary search for the origins of the universe, galaxies, our solar system, earth, life, diversity of living organisms, and the human body. The fields of nuclear physics, astronomy, geology, embryology, comparative anatomy, genetics, cell and molecular biology, and biochemistry inform the search for physical origins. Metaphysical questions about origins are informed by scholars in Biblical analysis, theology, philosophy, and literature. Each student will develop an annotated bibliography and a scholarly paper integrating course content with his/her own worldview.

The criteria optimally filtered for participants with relatively advanced biology knowledge and reasoning skills. Completion of the Origins course guaranteed exposure to issues surrounding evolution and creationism. Enlarging the participant pool to recent graduates allowed for compelling reflection on college experiences. Twenty-one potential participants were the entire cohort who had completed the Origins course and fit the study criteria. No selection was made in terms of students' initial or final views of either science or religion. Three potential participants who were recent graduates were inaccessible and three declined participation in the study. Fifteen study participants included six female undergraduates, one male undergraduate, six female graduates and two male graduates.

\section{The Role of the Researcher}

During the study, one of the authors was a faculty member at the study site and as the primary researcher conducted all interviews and field 
observations. All study participants had previously taken a science or science education course from the researcher, but no participant was enrolled in the researcher's courses during the research. Of the 18 potential participants who were accessible and contacted for this research, 83\% elected to participate in and complete the study. Despite the busy schedules of participants, several of whom were in professional or graduate studies, participants appeared eager to help the researcher. The high participant rate indicated that the research topic was relevant to participants and the existing rapport between the researcher and participants was a positive aspect of the study.

Naturalistic inquiry is interpretive research in which the researcher is the main instrument for data collection and analysis (Merriam, 1998). The biases, values, and personal experiences of the researcher may influence the research process and warrant identification in a study (Creswell, 2003). The primary researcher's perspectives on religious belief and evolution were rooted in growing up in a Christian home. Having attended conservative Christian schools and a Christian college as a physics major with little exposure to evolution, the primary researcher was highly suspicious of biological evolution. However, over several years prior to conducting this study, the primary researcher came to accept evolution through reading a number of books written by Christian scientists (e.g., Miller, 1999) and interacting with colleagues at the study site university who served as examples of Christians who affirmed evolution. As with any naturalistic research, this study endeavored to represent phenomena from the participants' points of view (Merriam, 1998). However, the primary researcher's personal experiences and altered perspectives on evolution played a key role in designing the study and interpreting the data that represented participants' experiences in reconciling evolution and personal religious belief.

\section{Limitations of the Study}

This case study was bounded to biology-related undergraduate seniors and recent graduates from a single Christian university. The selection of participants was purposefully designed to provide greatest insight into the processes that university students with religious beliefs experience when studying evolution. The variety in personal values, experiences, dispositions, and backgrounds that participants naturally 
brought to the study facilitated a rich understanding of each individual and a broad, holistic picture of all participants.

\section{Data Sources}

The broad sources of data in this study included semi-structured interviews, an Evolution Attitudes survey, and scholarly papers. Data were collected from December 2006 to August 2007. A dual interview design was utilized. The first interview investigated the participants' worldview using Fowler's (1981) structural-developmental theory of "stages of faith" which describe the cognitive rationale and affective response in shaping one's world. The interview protocol utilized Fowler's Manual for Faith Development Research (Fowler, Streib, \& Keller, 2004). Sample questions are available as supplementary material accompanying the online article (Interview Protocol S1). Faith development interview data were analyzed and coded similarly to all the data sources in this study. As the focus of this article centers on participants' experiences and perceptions in reconciling evolution and personal religious beliefs, the faith stage developmental outcomes are not addressed in this paper, but are found in Winslow (2008).

The creationism-evolution interview was conducted approximately a week following the first interview and explored participants' perceived conflicts between evolution and personal religious beliefs. The interview protocol, created by the primary researcher, is available as supplementary material accompanying the online article (Interview Protocol S2). The second interview included the Evolution Attitudes Survey (Ingram \& Nelson, 2006), which helped participants transition from the first interview of faith development issues to the second interview's exploration of evolution and creationism views, and provided context for further exploration and clarification during the interview. Additionally, the survey results were another source of evidence to complete a comprehensive understanding of participants' perspectives.

As an Origins course assignment, participants wrote a "scholarly paper" that integrated course content with their own worldview. The scholarly paper was a rich source of information that represented the participants' views on evolution. The carefully prepared contents of the scholarly paper were an effective complement to the informal, spontaneous interview responses. Prior to the second interview, the 
researcher read the participants' scholarly papers to identify aspects of their beliefs and views on evolution for further exploration.

Participants were given opportunity to review their interview transcripts to check for accuracy and provide clarification. In addition, participants were provided personal portraits that described their views of creationism and evolution. Participants returned a member check form with feedback. The purpose of the member checks was to ensure accuracy in description and fidelity to participants' perspectives. Participants' responses to their portraits through the member checks were consistently positive. Four participants requested minor modification to single paragraphs in their portraits to more accurately reflect their perspectives. One participant wrote on her member check in response to her portrait, "I just read the paper-perfect! Sorry, but there were no comments that needed to be made. You worked through the progression of my inner struggles precisely and represented my views exactly. Thank you for this work." Member check data were integrated into the main study data for analysis and coding.

The primary researcher observed the Origins course in the spring of 2007. Descriptive fieldnotes offered insights into the milieu in which students processed their understanding of evolution and personal religious beliefs. The researcher observed from the back of the classroom and took notes of the professor's presentations and professorstudent interactions. All 15 participants in this study had completed Origins in the previous 2 years before spring 2007; therefore, none of the participants were formally observed in Origins. However, discussion with the Origins professor revealed that the course had not been significantly changed in the semester the researcher observed the course, and an identical syllabus was used in the previous 2 years.

\section{Methods of Analysis}

Data analysis was a multi-step process that included multiple readings and coding of the interview transcripts, documents, and fieldnotes. Scrutinizing data for regularities of words, phrases, behaviors, and participants' ways of thinking enabled the identification of codes assigned to units of data. The development of codes in the first reading of both interview transcripts centered on participants' views of creationism and evolution as well as the influences and events that fostered those perspectives. The preliminary list after the first reading 
contained 46 codes such as "parental influence," "Bible," "fear or anxiety," and "domains of science and religion." The codes were checked with the research questions to ensure the questions were adequately addressed.

The initial list of 46 codes was then used in a second reading to code line-by-line the interview transcripts, scholarly papers, and participants' member check forms. Any new codes that developed during the course of the second reading were rechecked by another search through the data using key words and phrases. For example, the researcher read through participants' key statements multiple times in developing their portraits after the second reading, and noticed that many participants referred to the scientific evidence of evolution. Although these references were subtle in the first and second major reading of the entire data, subsequent reading revealed that many participants placed an importance on evidence in coming to an acceptance of evolution, and that participants esteemed evidence in unique ways that affected whether they accepted or rejected evolution. Consequently, the researcher searched through the data, carefully read the poignant sections, and coded for "evidence."

At the end of the second reading, some codes were subsumed by other codes or adapted to fit the emergent patterns. For example, an initial reading produced the separate codes of "church pastor" and "Sunday School teacher" as influences. However, after a second reading of the entire data, little distinction was needed between the two codes and both were combined under a new code entitled, "Christian adult influence." The final list of codes was streamlined to 41 codes including, for example: authors and pundits; friends; university classes; anger and frustration; love of science; pressure and conflict; abiogenesis; definitions of evolution; salvation issue, etc. Based on their commonality, the codes were aggregated into four groups: influences; expressed emotions, and attitudes; conceptions of science and evolution; and religious ideas and implications of evolution. The codes within each of the four groups were not exclusive. For instance, the code "Bible" was listed under the "influences" group, but also related to the "religious ideas and implications of evolution" group. The four code groups facilitated organization of the data and offered explanatory clarity to the codes.

Coded material was consolidated from participants' interview transcripts and documents into separate files. The winnowed data allowed 
individual codes to be studied in an aggregate form of all participants' statements associated with that code. Merriam (1998) writes that the devising of themes "is largely an intuitive process, but it is also systematic and informed by the study's purpose, the investigator's orientation and knowledge, and the meanings made explicit by the participants themselves" (p. 179). As the primary researcher became increasingly familiar with the data through multiple readings and refinement of codes, themes emerged from the patterns evident within the data. The patterns were written into themes and sub-themes, organized into three categories based on their similarities, and refined for consistency and accuracy by reference to the original data.

A faculty colleague of the primary researcher acted as a peer debriefer and the two met monthly during the data collection and analysis, until the final report was produced. The peer debriefer provided insight into the coding procedures and the construction of categories and themes. Additionally, the peer debriefer acted as an internal auditor for the study: certifying the study's credibility through an audit trail, examining the data analysis procedures, and establishing that the study findings were grounded in the data.

\section{Results}

The following is a description of the study's findings. Themes and subthemes are provided with commentary and relevant data that address the study's central question and sub-questions. The Results Supplement contains a description of the Origins course and learning environment in which the participants studied evolutionary theory and is available as supplementary material accompanying the online article.

\section{Summary of Participants' Views on Creationism and Evolution}

Participants' views fell into the dominant Christian categories regarding origins, described earlier as: Young Earth Creationism, Progressive Creationism, and theistic evolution. Table 1 summarizes participants' childhood beliefs, including the sources for those beliefs, and their views on creationism and evolution at the time of the study. Eleven participants identified their denomination as the same as the study site university. Three participants came from other denominations 
Table 1. Participants' childhood beliefs and views at the time of study

\begin{tabular}{llll} 
Participant & Childhood beliefs & Influenced by & Views at the time of study \\
\hline 1. Gail & Young Earth Creationism & Parents & Theistic evolution \\
2. Stephanie & Young Earth Creationism & Church & Theistic evolution \\
3. Megan & Young Earth Creationism & Father (pastor) & Theistic evolution \\
4. Diana & Theistic evolution & Father (geologist) & Theistic evolution \\
5. Ashley & Young Earth Creationism & Mother & Progressive creationism \\
& & & with elements of \\
& & theistic evolution \\
6. Tiffany & Young Earth Creationism, & Church & Theistic evolution \\
& accepted non-human & & \\
7. Jennifer & Young Earth Creationism & Parents & Theistic evolution \\
8. Rachel & Young Earth Creationism & Father (pastor) & Theistic evolution \\
9. Heather & Young Earth Creationism & Parents & Theistic evolution \\
10. Brittany & Young Earth Creationism & Church & Theistic evolution \\
11. Nicole & Young Earth Creationism & Parents & Theistic evolution \\
12. John & Young Earth Creationism & Parents & Theistic evolution \\
13. Elizabeth & Young Earth Creationism & Church & Theistic evolution \\
14. Michael & Young Earth Creationism & Mother & Theistic evolution \\
15. David & Young Earth Creationism & Mother & Young Earth Creationism \\
\hline
\end{tabular}

different from the study site university while one came from a Catholic background. As Table 1 shows, during childhood most participants believed in Young Earth Creationism and the denomination of Christianity did not appear to make a difference in their childhood views. Many participants reported that their strong creationist and anti-evolution beliefs were due to their parents' influence. Other participants remarked that they simply assimilated creationist beliefs from what they heard in church.

Two notable exceptions in Table 1 are Diana, Participant 4, and Tiffany, Participant 6. Diana's father was a geologist and taught her from a young age to see evolution as valid and without contradiction to her Catholic faith. Tiffany was also unique in that she accepted non-human evolution while in high school when she discovered that evolution “didn't necessarily mean that God didn't create everything." Still, Tiffany faced uncertainty about human evolution. Both Diana and Tiffany were surprised at how many of their fellow classmates in the Origins course struggled with evolution. Tiffany said, "I didn't even realize that until I actually took that Origins course and there were kids in there. . . [where] the light bulbs were just coming on and I was 
like [?-quizzical, bewildered expression].” Diana and Tiffany's relative ease with evolution contrasted with most other participants who struggled to overcome their distrust of evolution. Many participants did not realize that a Christian could accept evolution until they arrived at the study site university. Most participants had some exposure to learning evolution in a freshman Zoology course with the same professor who taught the Origins course. However, those who eventually accepted evolution reached that position late in their university tenure and only through a process of conflict resolution and apprehension.

In contrast to their childhood creationist beliefs, most participants, as reflected in the last column of Table 1, held a theistic evolution view at the time of the study. Thirteen participants affirmed that God created through evolution. Two noticeable exceptions are Ashley, Participant 5, and David, Participant 15. David espoused a traditional, Young Earth Creationist view. Ashley's views were a hybrid model of Progressive Creationism and theistic evolution perspectives. Having come from a strong creationist background, Ashley adapted her views while in college to assert that God specially intervened to create an initial line of ten thousand species through which evolution took over to result in the diversity of life on earth.

To summarize, most of the participants were raised during childhood to believe in Young Earth Creationism. Many participants had no concept of theistic evolution and instead held anti-evolution perspectives when they entered the study site university as freshmen. However, most participants came to accept evolution as God's mechanism for creation while at the study site university. These trends are further explored below.

Introduction to Categories, Themes, and Sub-Themes

The themes and sub-themes are key outcomes of the data analysis of this study. Categories are groupings of themes to facilitate an understanding of participants' experiences in negotiating evolution and personal religious beliefs. Category 1 delineates the primary factors that influenced participants' views on evolution and creationism. Category 2 examines the meaning participants gave to science and religion in their lives. Both categories provide the context for and lead to Category 3, which describes the process of participants' reconciliation of evolution and personal religious beliefs. 
As this study is a naturalistic inquiry, the themes and sub-themes are not quantitative. Instead, descriptive words such as "most," "many," and "some" convey the extent of a pattern to which the theme or sub-theme applies. "Most," in the context of this study with 15 participants, indicates ten and greater, or at least two-thirds of the participants, but not all participants. "Many" is five or more but less than most. "Some" indicates less than five but still represents a meaningful extent. Table $\mathbf{2}$ is a summary of the categories and themes. The subthemes are further delineations under each theme and are presented within the discussion below.

\section{Category 1: Influences on Participants' Views of Creationism and Evolution}

Theme 1.1 states that parents were a strong influence in participants' lives. This theme was an important factor for Theme 3.2 in many participants' anxiety in accepting evolution for fear of what they

Table 2. Overview of categories and themes

\begin{tabular}{ll} 
Category & Theme \\
\hline $\begin{array}{l}\text { 1. Influences on participants' views } \\
\text { of creationism and evolution }\end{array}$ & $\begin{array}{l}\text { 1.1. Participants viewed parents as a strong } \\
\text { influence }\end{array}$ \\
$\begin{array}{ll}\text { 1.2. Participants viewed professors as influential } \\
\text { role models }\end{array}$ \\
$\begin{array}{l}\text { 2. Participants' perspectives on the } \\
\text { domains of science and religion }\end{array}$ & $\begin{array}{l}\text { 2.2. Participants trusted and valued science } \\
\text { as a way of knowing } \\
\text { their personal religious beliefs }\end{array}$ \\
$\begin{array}{l}\text { 2.3. Participants desired a positive relationship } \\
\text { between science and religious beliefs in their } \\
\text { worticipants' reconciliation of evolution } \\
\text { and personal religious beliefs }\end{array}$ & $\begin{array}{l}\text { 3.1. Most participants viewed evolution as a } \\
\text { valid explanation for the diversity of life } \\
\text { on Earth }\end{array}$ \\
$\begin{array}{l}\text { 3.2. Most participants' acceptance of evolution was } \\
\text { a process of conflict resolution and } \\
\text { apprehension }\end{array}$ \\
$\begin{array}{l}\text { 3.3. Four factors facilitated participants' } \\
\text { acceptance of evolution: relying on the } \\
\text { evidence for evolution; negotiating Genesis as } \\
\text { non-literal; recognizing evolution as a non- } \\
\text { salvation issue; and observing professors as } \\
\text { role models of Christians who accept evolution }\end{array}$ \\
\hline
\end{tabular}


perceived would result in their parents' chagrin. All 15 participants testified to their parents' enduring influence on their lives. The following sub-themes are characterizations from the participants' stated viewpoints. None of the participants' parents were interviewed for this study and the participants' accounts of their parents' beliefs may not necessarily conform to their parents' actual beliefs.

Sub-theme 1.1.1 states that most participants articulated that their parents raised them to believe in creationism. Diana, Participant 4, was the only exception to this dominant trend as discussed earlier. Two patterns emerged from the other 14 cases in this study: parents clearly espoused creationism in the home; and participants vicariously perceived their parents' belief in creationism through the church culture in which they were raised.

Eight participants voiced that one or both parents expressed a strong belief in creationism throughout the participants' childhood and expected participants to hold similar beliefs. For example, Nicole, Participant 11, stated, "My family was. . . very much of the Genesis is the golden rule. God created the earth in 7 days. That's how it happened, no questions asked. If you asked questions,. . . you were thinking too hard about it." In five of the eight cases, parents were reportedly so fervent in their creationist beliefs that they engaged in heated arguments with the participants who were in the process of accepting evolution while at the university. In the other three cases, the participants evaded conflict with their parents by avoiding any discussion about evolution.

In contrast to the previous eight cases, six participants perceived that their parents believed in creationism, but primarily because creationism was part of the participants' upbringing in the church. In other words, parents' expression of their belief in creationism was less pronounced than in the other eight cases. For example, Ashley, Participant 5, noted, "I'm pretty safe in saying from the time I was born until high school senior year, the first chapter of Genesis was literal. That's just how I was raised. . . Nothing was ever questioned." Ashley clarified, "Not that they [my parents] said everything in the Bible is word for word true,. . . but no one ever said the opposite, that it wasn't literal. So I just assumed that it was."

Sub-theme 1.1.2 states that many participants reported their parents actively pressured them to reject evolution. Many participants recalled the anti-evolution sentiments they had heard from their parents in 
childhood. Asked about where she acquired her negative view of evolution before enrolling at the study site university, Rachel, Participant 8 , recalled hearing her parents' conversations, such as, "Darwin is a tool of the devil and. . . he's led so many people astray from God and that's just terrible and don't get sucked into that because it's the devil working through him.” Rachel added, "I'd be kinda listening in" and soon enough, she found herself saying to her high school friends, "Oh yeah, I can't believe these evolutionist liberals." She added, “Those two words always went together-liberal and evolutionist!"

For many participants, the anti-evolution sentiments they heard in childhood continued while learning evolution at the study site university. Several participants asserted that their parents expressed displeasure that their daughter or son was learning evolution at a Christian university. When Jennifer, Participant 7, took the Origins course, she began to share her new ideas about evolution with her parents. She recalled they became increasingly "apprehensive about things." Jennifer could tell by their body language and, as she described,

[the] kind of looks they give me whenever I'm like, "Well, what about this [evidence for evolution]?" Because I get real kind of built up about things like this. . . and I'm like, "But this is what I learned in college" [shouting as she says this] and I bring my papers home and I'm like, "Look at this" [pounding the table] and they're like a little skeptical. . . You kind of see it in their eyes and they furrow their brow and stuff like that.

Five participants, including Jennifer, recounted their heated arguments with their parents over evolution. The parents reportedly denied evolution as a valid theory and charged evolution as contradictory to the Bible. For example, Rachel, Participant 8, recalled tense exchanges with her father where they would get into arguments and "become angry." She cited his comments, "Why are you thinking this way? We sent you off to a Christian school [and] you are learning all this liberal garbage?" Furthermore, all five participants indicated their parents viewed a literal interpretation of Genesis as a necessary condition for salvation. Rachel remarked, "I have been taught my whole life you can't be both [a Christian and an evolutionist], that's just not how it works." 
The emotional stress that many of these participants experienced in forming increasingly independent views about evolution in direct opposition to their parents cannot be understated. Rachel, Participant 8, remarked that arguments with her father never degenerated into "hatred," but it did create, as she described, "kinda a space between us." She wrote in her scholarly paper,

I have to ask God to give me patience to not hate the men who cause me and my dad to argue about origins. I think that if they could just realize that science is not out to destroy God then maybe they would give it a chance.

In spite of past or ongoing struggles over evolution, many participants maintained a close relationship with their parents but claimed a worldview unique from their parents. For example, Jennifer, Participant 7, who was a single child, remained close to her parents and said, "I've come to respect their opinions about certain things a lot more. At the same time, I've come to realize that maybe they're not always right in every single thing. . . It's okay for me to think differently than them."

Other factors, such as church, friends, siblings, and spouses were construed by participants as relatively moderate influences in their lives. For example, when participants expressed apprehension in their encounters with evolution, not a single participant expressed anxiety about the response of their church or pastor. Instead, most were worried about the reaction of their parents. Summarizing Theme 1.1, participants viewed parents as a strong influence in their lives. Most participants articulated that they were led to believe in creationism during childhood, either directly from their parents or within the church. Many participants reported that their parents aggressively pressured them to reject evolution while studying evolutionary theory at the study site university.

Theme 1.2 states that participants viewed professors as influential role models. All 15 participants stated that professors had made a significant impact in their lives. Seven participants expressed a respect for professors who were genuine and forthright in presenting evolution in a Christian context. Rachel, Participant 8, noted that it wasn't enough for the Origins professor to simply claim to be both a Christian and evolutionist-she needed to see it demonstrated. Rachel explained, 
They can say they're Christian and be an evolutionist, but it would really help for Dr. [Origins professor] because she actually showed you. She'd talk about God and. . . then she also talked about evolution and so you kinda had to reconcile the two. . . My whole life it was just two things that were separate and they must stay separate, but with her they kinda came together and you had to reconcile them.

Rachel's statements support another pattern which emerged: many participants respected professors who demonstrated a commitment to both science and religious beliefs. Six participants valued the influence of professors who authenticated a positive relationship between science and religious faith instead of isolating the two domains from each other.

Summarizing Theme 1.2, all participants viewed their professors as influential role models. Many participants appreciated the authenticity and transparency of their professors who were straightforward in communicating their views on evolution and their religious beliefs, thus serving as examples in developing a positive relationship between science and religious beliefs. The Category 1 themes of parental and professorial influence are salient factors in participants' experiences in reconciling evolution and personal religious beliefs.

Category 2: Participants' Views on the Domains of Science and Religion

Category 2 provides a context for better understanding participants' views on evolution as given in the Category 3 themes. Participants' views of evolution were situated within their encompassing views of science. Similarly, participants' commitments to retaining personal religious beliefs while accommodating evolution were contextualized within their perspectives on the verisimilitude of religion in general.

Theme 2.1 states that participants trusted and valued science as a way of knowing. Eight participants said they "loved" science or some aspect of science. Many participants expressed the notion that science brought meaning to their lives, as demonstrated by Tiffany, Participant 11: "Science. . . helps me to ask questions about the way things are and. . . that brings joy to my life, to be able to notice something 
and to maybe wonder about it and then to be able to. . . figure it out." Twelve participants articulated one or more reasons for their trust in science including the scrutiny of the peer review process in scientific publishing, the verification process that comes through replication of scientific experiments, and that science is based on observation and evidence. Several participants thought that openness to change in light of new evidence was a positive element of science. Still, many participants noted that scientists are human and thus have biases.

In the Evolution Attitudes Survey (Ingram \& Nelson, 2006), Item 4 states, "Scientists who believe in evolution do so mainly because they want to, not because of any evidence." Participants who strongly disagreed or disagreed with this statement indicate a trust that scientists are generally unbiased and use evidence to support their acceptance of evolution. The survey data show nine participants strongly disagreed and five participants disagreed with Item 4. David, Participant 15, was the only participant to agree with the statement and indicate a distrust of scientists who supported evolution. David argued, "Science is trustworthy as long as it keeps questioning itself," but claimed evolution had become a hegemony within the scientific establishment.

Summarizing Theme 2.1, participants trusted science as a way of knowing. That trust was qualified by an awareness of science as a human endeavor. Participants did not see science as infallible. However, many participants confidently claimed that scientific thinking was embedded in their worldview.

Theme 2.2 states that most participants trusted and remained committed to their religious beliefs. The researcher asked the question, "How do you feel about the trustworthiness of your religious beliefs?" None of participants asked what was meant by "religious belief" and no definition was provided in the interview protocol. However, participants answered the question without pause. From the context of their answers, participants appeared to interpret personal religious beliefs as core convictions about reality and a moral code to decipher a right course of action and that which is true. For example, Gail, Participant 1, described her religious belief system, “It's. . . what I read in the Bible and what I hold to be true."

As participants conversed about their beliefs, they conveyed a sense of ownership. Michael, Participant 14, even joked about this. When asked how he felt about the trustworthiness of his religious beliefs, 
Michael responded, "Well I trust those because they're mine [italics added]." Gail, Participant 1, sought to clarify the place of science and religion in her life: "If I had to distinguish between science and religion-religion would be my [italics added] foundation, what I stand on and science would be something that I hang on to." She added, "I would say that religion is my [italics added] core and science is just, it's affecting everything, but it's not what I go to all the time." To paraphrase Gail's comments and those of several other participants, "Science is something I do or is one way I think, but my religious beliefs go to the core of who I am."

Theme 2.3 states that participants desired a positive relationship between science and religious beliefs. All 15 participants expressed a desire for science and religion to co-exist in a compatible relationship. Nuances emerged as participants articulated a variety of possible viewpoints on the domains of science and religion as displayed in the first column of Table 3. Participants' active expressions are differentiated in the headings of Columns 2 through 4 .

Table 3 neither represents an exhaustive summary of all possible viewpoints of the domains of science and religion, nor does it portray an objective definition of the proper relationship between science and

Table 3. Participants' views and active expressions on the domains of science and religion

\begin{tabular}{|c|c|c|c|}
\hline $\begin{array}{l}\text { View of science } \\
\text { and religion }\end{array}$ & $\begin{array}{l}\text { Used science } \\
\text { and religion to } \\
\text { validate each other }\end{array}$ & $\begin{array}{l}\text { Used religious } \\
\text { explanations to } \\
\text { solve perceived } \\
\text { scientific uncertainty }\end{array}$ & $\begin{array}{l}\text { Maintained distinct } \\
\text { boundaries between } \\
\text { science and religion }\end{array}$ \\
\hline $\begin{array}{l}\text { Science and religion } \\
\text { are integrated }\end{array}$ & $\begin{array}{l}\text { Diana, Participant } 4 \\
\text { David, Participant } 15\end{array}$ & No participants & No participants \\
\hline $\begin{array}{l}\text { Science and religion are } \\
\text { separate but interactive }\end{array}$ & No participants & $\begin{array}{l}\text { Ashley, Participant } 5 \\
\text { Brittany, Participant } 10 \\
\text { Elizabeth, Participant } 13\end{array}$ & $\begin{array}{l}\text { Gail, Participant } 1 \\
\text { Stephanie, Participant } 2 \\
\text { Megan, Participant } 3 \\
\text { Tiffany, Participant } 6 \\
\text { Rachel, Participant } 7 \\
\text { Jennifer, Participant } 8 \\
\text { Heather, Participant } 9 \\
\text { Nicole, Participant } 11 \\
\text { John, Participant } 12 \\
\text { Michael, Participant } 14\end{array}$ \\
\hline $\begin{array}{c}\text { Science and religion are } \\
\text { separate and isolated }\end{array}$ & No participants & No participants & No participants \\
\hline
\end{tabular}


religion. Instead, Table 3 is a collection of the participants' claimed viewpoints and active expressions. Row 1 may be conceptualized as a Venn diagram with significant overlap between the circles of science and religion. In Row 2, the circles of the Venn diagram are touching and interfaced, but not overlapping. Row 3 is analogous to Venn diagram circles that are separate and isolated. Even though no participant claimed this view, it is included in Table 3 because four participants explicitly said they thought this position was inappropriate and untenable. For example, Stephanie, Participant 2, said,

Anyone could take science and say, "Oh it has nothing to do with religion," and anyone can take religion and say there is no part of science in it so I think with the science background I have and the religious background I have, I think there's a way for them to exist together. . I don't think you have to be real hard on one subject and real hard on the other. . . [that] you can't have both.

Column 1 of Table 3 shows that most participants viewed science and religion as separate but interacting domains. However, participants' active expressions of science and religion did not necessarily match their claimed viewpoints. Column 2 represents participants who regularly used scientific and religious notions to explain each other. In this column, participants reconciled science and religion by intermixing the two. Column 3 represents participants who employed religious explanations to account for perceived gaps in scientific knowledge. For example, Ashley, Participant 5, claimed a separate but interactive view of science and religion but in her active expressions, she used religious explanations to solve perceived scientific uncertainty. In her incredulity that all organisms could evolve from a common ancestor, Ashley invoked God in creating an initial line of species with which evolution began. Column 4 represents participants who operationally did not mix science and religion: scientific problems were not solved by religious solutions; and science was not used to provide evidence for religious beliefs. These participants appeared to have reconciled science and religion by keeping the domains distinct.

All 13 participants in Row 2 in Table 3 indicated that prior to attending the study site university, they did not maintain any boundary between science and religion. Instead, science and religion, in their 
prior view, were integrated and each validated the other. In taking Genesis as literal, many of these 13 participants previously used religious notions to filter scientific theories (e.g., evolution) that they thought were true. Through their experiences at the study site university, these 13 participants transitioned from Row 1 to Row 2.

In contrast to the other 13 participants, Diana and David, Participants 4 and 15 respectively, did not transition from an integrated view of science and religion. David claimed, "I believe science does prove God. . . because we can't even go back to the beginning of the Big Bang.' David focused on what he perceived as cosmological and biological evolutionary problems to support his religious beliefs. Diana was more explicit in explaining her integration of science and religion, "My religious beliefs and my scientific beliefs go hand in hand. I don't ever separate the two. I don't think that they're two different worlds." However, Diana struggled to articulate why she thought so: "I think that this world is all one big science and religion ball. . . It's not one way or the other. It works together. It has to [italics added]." Diana's contention that science and religion must work together in an amalgamated manner appeared to be a position in which she found equilibrium. In order to remove dissonance, Diana simply stated that science and religion "have to" be in harmony.

Row 2 in Table 3 represents the view that science and religion are separate but interfacing domains. The 13 participants who claimed this position as a personal model cited two reasons. Many participants noted that science and religion ask completely different types of questions. For example, Elizabeth, Participant 13, said, “I don't think that they are trying to tell the same message. . . Science explains the how and when and religion is more like who and why. . . They describe different things." Many participants also noted that science is based on tangible evidence while religion is not. John, Participant 12, saw science and religion as "two separate types of worldviews" and clarified,

The way that they define things are different, because the Christian belief is based solely on faith. For me, there is no evidence, no hard fast evidence that I can see. . . Whereas science, you have hard fast evidence, something that you can put your hands on and see. 
Regardless in how participants in Row 2 viewed science and religion, variations occurred in the way they actually used the domains to support their perspectives on evolution. Elizabeth is a prime example of some participants' struggle to maintain a clear boundary between science and religion. At the conclusion of her Origins scholarly paper, Elizabeth wrote, "As long as these appropriate boundaries are maintained, interpretations will not be controversial, and all things will remain in harmony." Operating from this vantage point, Elizabeth would align with the last column in Table 3. However, when the researcher reminded Elizabeth of the "harmony" statement in her scholarly paper, she clarified, "You know, it's never complete harmony. There's always the thing about the cellular level but I think in general [italics added], it lives in harmony." Although she was unsure about the details of cellular evolution, Elizabeth confessed she was "still a little bit bothered" by "evidence against. . . cellular evolution like everything started as one cell." When asked whether these objections to cellular evolution could be proof of God directly intervening in a special act of creation, Elizabeth admitted, "I guess I do kind of stick God in there and say, 'Well, God did it.' I don't know how, but God did it where science can't explain it." Elizabeth appeared to violate her own written statement about maintaining the boundaries of science and religion and thus appears in the third column of Row 2.

Ten participants claimed that science and religion are separate, and actively maintained distinct boundaries in their discussion of evolution, which is the intersection of Row 2 and Column 4. Using words like compatible, harmony, and complement, most participants held the position that science and religion are not only reconcilable, but also positively interacting. Jennifer, Participant 7, articulated a position that is a fitting summary to most participants' positions about science and religion:

There are two separate windows - science and religion. . . You can mix the two and they go together just fine and everything. They don't conflict generally [italics added] but the stuff that you observe out of the science window isn't the same stuff that you're observing out of the religion window. You know religion is for the why and. . . the what's the purpose, whereas science is the what and the how it works. . If 
you are looking at it to ask the correct questions, they [the science and religion windows] might give you an answer that forms to create one big answer that complements with itself I guess, but you're not going to get the same answers out of both windows because it's two different questions.

The views of Elizabeth, Participant 13, and Jennifer serve to illustrate the differentiation of participants in the last two columns of Table 3. Elizabeth had misgivings about cellular evolution. Jennifer in her creation-evolution interview had also expressed lingering doubts about whether evolution could account for the complexity and diversity of life from a "single unicell." Elizabeth said science and religion are "generally" in harmony. Jennifer said science and religion do not conflict "generally." However, Jennifer alone recognized her doubts as scientific and did not insert God's supernatural intervention. Thus, Jennifer could say with confidence:

I can put them [science and religion] in harmony into my mind. I know some people say that they totally conflict and everything's hogwash and one or the other, but I think it makes sense that they can go together. I have to just. . . look at them within their own context. I can't just totally pull them out of context. If I did that of course, they wouldn't make sense.

The data in Category 2 indicate that participants trusted and valued science as a way of knowing. Similarly, participants trusted and were committed to their personal religious beliefs. Many participants viewed science and religion as separate but positively interacting domains. Most of these participants were operationally consistent with their views in maintaining clear distinctions between the two domains. However, some participants used religious explanations to solve perceived scientific problems.

Category 3: Participants' Reconciliation of Evolution and Personal Religious Beliefs

The previous two categories provide the context for Category 3, which explores the transitions that most participants underwent in accepting 
evolution. The reconciliation process proceeded amidst a complex lattice of competing emotions and influences. Theme 3.1 establishes that most participants came to view evolution as a valid explanation for the diversity of life on Earth. Thirteen participants espoused evolution in their interview statements as a valid theory. Item 1 in the Evolution Attitudes Survey stated, "Over billions of years all plants and animals on Earth descended from a common ancestor.' David strongly disagreed and Ashley disagreed with this statement. Nine participants agreed and four participants were undecided.

Most participants also accepted human evolution as evidenced from their interview statements, scholarly papers, and survey data. Five items in the Evolution Attitudes Survey dealt directly with human evolution. Marking strongly disagree or disagree on these statements would indicate an acceptance of human evolution. Fourteen participants demonstrated an acceptance of human evolution from their survey results. David, Participant 15, was the lone exception. Eight participants either strongly disagreed or disagreed on all five items while the remaining participants marked disagree with only one or two undecideds on the five survey items.

The results from the survey show a clear trend in 14 participants' acceptance of human evolution despite a relatively mixed response to Item 1, which said, "Over billions of years all plants and animals on Earth descended from a common ancestor.” For instance, Ashley, Participant 5, disagreed with evolution from a common ancestor, but she disagreed with every statement that rejected human evolution. Similarly, all four participants who were undecided on evolution from a common ancestor indicated by their survey responses that they accepted human evolution.

Participants saw ample evidence for human evolution in the Origins course both in textbook and lecture materials (see the Results Supplement for a description of the Origins course, available as supplementary material accompanying the online article). Accepting human evolution may require less scientific inference in the minds of the participants than the linking of all living things to a single ancestor billions of years ago. Many participants expressed that human evolution was part of the larger story of evolution. When asked if humans evolved, Gail, Participant 1, said, "For evolution to make sense in my head, we have to have had a common ancestor. If I understand evolution correctly, there has to be some ultimate beginning, which would be a link for all of us." 
Summarizing Theme 3.1, most participants accepted evolution as a valid explanation for the diversity of life on Earth, including the development of the human species. The remainder of Category 3 focuses on participants' reconciliation process in accepting evolution. Since David, Participant 15, was the only participant who rejected evolution, his case is less pertinent in Category 3. However, David's perspectives are used as a counter-example in several themes and sub-themes.

Theme 3.2 states most participants' acceptance of evolution was a process of conflict resolution and apprehension. Eleven of the 14 participants who accepted evolution discussed an affective response to learning about evolution in the context of their university studies. One of the three exceptions was Diana, Participant 4, who was taught about evolution in childhood by her father. The other two exceptions, Tiffany and Michael, Participants 6 and 14 respectively, appeared to be relatively unaffected emotionally in their encounters with evolution. When Tiffany encountered evolution in high school biology class, she said biological evolution simply made sense to her and that "it didn't have to be that black and white" between evolution and her religious beliefs. Michael remarked that once he became more open-minded about the Bible near the beginning of his university experience, there was no further reason for conflict.

Contrary to the experiences of Tiffany and Michael, most participants who came to accept evolution reported that the process was journey-like and took several years. Some who learned about evolution in their freshman Zoology class didn't resolve the issue in their minds until their junior or senior year. In many cases, the process was a slow accumulation of scientific evidence from various science courses. Many participants reported that Origins was a semester-long process of working through perceived conflicts. Ashley, Participant 5, described her experience in the course: "There you were, a whole semester, just basically ripping your hair out about where you stand."

Some participants mentioned they had "a-ha" moments along the journey. A few participants encountered a new perspective in a lecture or in a book, and their ideas about evolution and personal religious beliefs suddenly found greater clarity in the context of each other. However, these advances were steps along an extended journey. Many participants indicated that the process was a tug-of-war experience. They were pulled back and forth in deciding what scientific aspects to accept and how their religious beliefs would mesh with that 
new scientific acceptance. The comments of Ashley, Participant 5, illustrate the struggle:

I wanted to please both sides of myself. I wanted to please the science part of me but I also wanted to be true to the faith part of me and I wanted to get right in the middle and make sure both were alright and sometimes it's not possible.

Later in her interview, Ashley also remarked, "I felt like you'd get three steps ahead and you'd be 'Alright' and then five back!. . . And it was just a constant thought process. . . about where do I stand on this new issue."

Jennifer, Participant 7, joked about trying to find closure on human evolution saying, "When it [the Bible] says man was created instantaneously, one [evolution] says man was created over time, that was hard, but we eventually worked that one out." Asked what she meant by "we," Jennifer laughed and offered as an explanation, "Well me, myself, and I." Her joke implies the internal, contentious, decisionmaking process to which many participants similarly alluded.

The data indicate two primary sources of anxiety: participants' awareness that the beliefs they once thought so sacrosanct were beginning to change; and participants' apprehension about how they would defend an emerging acceptance of evolution to their parents. Ashley, Participant 5, said that learning about evolution "was a culmination of your thoughts for so many years being shattered and then you're picking pieces here and there and adding your own.' She expressed a personal sense of shock in first learning that a Christian could accept evolution. A look of exasperation came over Ashley's face when she reflected on that new realization her sophomore year when a guest lecturer spoke on campus about theistic evolution. With a laugh of incredulity, she said,

Now do you see what I mean about being blindsided or bombarded with things that for 18 or 19 years you've held true? I mean, to me, it's almost like for 23 years believing that my mom and my dad are my parents and then one day, them saying, 'No, you're adopted.' That's kinda like what it was to me. Just this truth for so long and then you're just like, 'What?!' That's how out of the blue it was to me [italics added]. 
Throughout many participants' recollections was an underlying current of anxiety in becoming aware that some of their religious beliefs were changing for the first time.

Participants who accepted evolution worried about how they would be viewed by their parents. As discussed in Theme 1.1, participants asserted their parents were a strong and continuing influence in their lives while at the study site university. Eight participants indicated that they either had experienced conflict with their parents over evolution or were too worried to broach the issue of evolution with their parents. Megan, Participant 3, still hadn't discussed evolution with her parents in the year since she took Origins. She said, "I'm kinda.. . . scared about talking to them [about evolution]." To summarize Theme 3.2, most participants' acceptance of evolution was a process of internal conflict resolution and apprehension about the changes in their own religious beliefs and what their parents would think about their acceptance of evolution.

Theme 3.3 states that four factors facilitated participants' acceptance of evolution. The interview protocol did not specifically ask participants to identify critical factors that they considered were crucial to accepting evolution. However, as the participants recounted their stories, patterns emerged from the data to suggest that four factors were important as part of the process of accepting evolution. Theme 3.3 does not assert that the four factors were a requisite for accepting evolution but instead helped move forward the process of accepting evolution. Each of the factors is discussed below in a sub-theme.

Sub-theme 3.3.1 states that the evidence for evolution was an important consideration for most participants who accepted evolution. A common thread evident in many participants' dialogue was their dependence on the scientific evidence. Ten participants specifically said the evidence for evolution was incontrovertible. Several participants articulated that in the past they took their parents' or teachers' word at face value but now demanded evidence from their authority sources to back up their statements. Rachel, Participant 8, noticed herself becoming more reliant on evidence to adjudicate her positions and reflected, "When I was younger, I took everything that everyone said at face value. . . and if an adult said it, it must have been true." Rachel said that as an adult, her line of questioning is now: "Why do you think that? Can you prove like more evidence as in why and not just tell me because?" Rachel's comments clarify that many 
participants had transitioned to relying on evidence to support what they held as true. In the context of science, that reliance was on scientific evidence, and many participants said the evidence for evolution was overwhelming.

David, Participant 15, was the only participant to categorically deny evolution. He appeared to operate with a mental filter that collected only ideas and purported evidence that supported his existing creationist notions. Incontrovertible evidence for evolution apparently slipped through David's filter without serious consideration. David was familiar with Intelligent Design arguments regarding the irreducible complexity of biological systems such as blood-clotting mechanisms and the bacterial flagellum (Behe, 1996), which he posited could not be explained by evolution. The researcher, in an effort to remain neutral and not broach the fact that science currently has valid explanations for these mechanisms (Miller, 1999; Pallen \& Matzke, 2006), asked David how he would react if science found a naturalistic explanation to these systems. David referred to a historical example to state his response:

If they prove it right, I mean everyone from Galileo's time, they didn't want to believe the earth wasn't the center of the universe and he proved that false. . If I go to not take those, then I cannot call myself a scientist. If they provide the facts and give them-show they are true, then-and I don't take them, I can't consider myself a scientist.

A careful inspection of David's statements reveals that he never said he would accept the evidence, even if shown to be "true." Ironically, David's reference to Galileo is fitting. Several of Galileo's most vocal critics in the early seventeenth century refused to look through Galileo's telescope (Sobel, 2000). However, several prominent Jesuit astronomers looked through the telescope and "did not deny the evidence of their senses" (Sobel, 2000, p. 40) and affirmed the Copernican Theory. It appeared as if David was unwilling to look through the telescope.

Sub-theme 3.3.2 states that negotiating Genesis as non-literal was important for most participants who accepted evolution. Most participants asserted they had been raised to believe in a literal interpretation of Genesis by their parents. Sub-theme 3.3.2 investigates why 
a negotiation of Genesis was important for many participants to accept evolution. All participants discussed the past and ongoing importance of the Bible in their lives. Many participants demonstrated an intimate knowledge of the Bible by referencing and quoting scripture to support their statements. The notion that the Bible is literal was taken for granted by many participants in childhood. However, participants recognized that a literal interpretation of Genesis was at odds with evolution. Megan, Participant 3, wrote in her scholarly paper, "A strictly literal interpretation of the Bible does not mesh with the evidence discovered by science, especially the discoveries made within the past century."

Furthermore, some participants recognized that an acceptance of evolution would not jeopardize their salvation. This thought process can be paraphrased, "My salvation is unaffected because I can concomitantly accept evolution and remain true to the Bible as it should be interpreted." These paraphrased statements are echoed in the comments of Gail, Participant 1. When asked what had made the crucial difference in turning the corner in accepting evolution, Gail responded that it was when the Origins professor "brought up the fact that, 'This isn't crucial to your salvation and we're not saying that God didn't start it all, that God's not behind it. We're just saying here are all the natural laws. . . [that] God put in place."' Gail recognized through her professor that evolution did not countermand a belief in God or in the Bible.

Gail's comments link Sub-theme 3.3.2 about Genesis as non-literal with Sub-theme 3.3.3, which posits the importance of many participants' recognition that an acceptance of evolution and salvation are unlinked. Many participants prior to attending the study site university never considered a Christian could accept evolution. At some point, participants who held that assumption had to evaluate its legitimacy before accepting evolution. Furthermore, five participants had to deal with parents who were dubious that an acceptance of evolution was uncoupled with spiritual standing. For example, Jennifer, Participant 7, reported she would go home and tell her parents about her Christian professors who affirmed evolution. She would use that as "leverage" and inform her parents, "So it must be okay. God's not gonna strike you down cause they're still alive kind of thing." Jennifer's joking notwithstanding, many participants had to make an 
intentional or unconscious break with their previous assumption that an acceptance of evolution placed a Christian's salvation in serious jeopardy.

Sub-theme 3.3.4 states that observing a Christian professor model a commitment to evolution was important in many participants' acceptance of evolution. The general influence of the professor as a role model was explored in Theme 1.2. Here, Sub-theme 3.3.4 focuses on how Christian professors were an important factor in facilitating an acceptance of evolution. The data show that participants viewed their professors as validation that a Christian could unapologetically accept evolution. Megan, Participant 3, serves as a poignant example. She first learned about evolution while writing a report for a high school biology class. Megan reported that she "paid no attention" to what she wrote and simply completed the assignment for a grade. But at the university, she remarked, "Here are all these Christians around me and a Christian professor who is having this kind of idea and that actually made me open up to it." Megan admitted,

I think that if I had gone to a public university and had the same teachings, I don't know if I would have been open to accepting it. Maybe I would have just done the same thing I did in high school when I had to write that paper-just kind of ignore it.

Rather than ignoring evolution, Megan could consider an acceptance of evolution that was so powerfully affirmed through her Origins professor and bring her to a point where she could say, "Maybe I can believe that too."

David, Participant 15, once again comes into sharp contrast with the other participants in this study. While he credited his religion professors for shaping his ideas about Christianity, he made no mention of any of his science professors as role models. David appeared so firmly entrenched in his anti-evolution stance that he remained unmoved by the example of his Origins professor and other science professors who affirmed evolution. His mental filter that collected purported evidence in support of his existing notions of creationism and dismissed conclusive evidence for evolution appeared to extend to authority sources as well. 
Summarizing Theme 3.3, four factors facilitated many participants' acceptance of evolution. Participants' cited Christian professors who avowed evolution. Other important factors included a reliance on evidence for evolution, a determination of Genesis as non-literal, and recognition that an acceptance of evolution did not jeopardize salvation.

\section{Discussion}

The categories, themes and sub-themes in this study serve a heuristic purpose as an exploration into the intricate issues that some Christian university students bring to the table in learning about evolution and the processes by which they seek reconciliation between evolution and their personal religious beliefs. The rich description of this naturalistic study lends insight and offers relevance to researchers and educators seeking insight into those complex processes. Although this study focused on the reconciliation process for biology-related majors and recent graduates from a Christian university setting, the nuances of Christian students' resistance to learning evolution are germane to a secular university environment. According to a 2004 study on the spirituality of college students, $26 \%$ of freshmen at colleges and universities across America considered themselves to be born-again Christians (Astin et al., 2005). Other studies have shown that a large number of college-bound Christians choose to attend secular colleges and universities (e.g., Henderson, 2003).

Most research on secular university students' views of evolution has focused on understanding (e.g., Lord \& Marino, 1993), academic achievement (e.g., Ingram \& Nelson, 2006), and acceptance (e.g., Rutledge \& Warden, 1999; Sinatra et al., 2003). None of these studies focused on an in-depth exploration of Christian students' views. A few studies (e.g., Jackson, Doster, Meadows, \& Wood, 1995; Ebenezer, 1996) have explored the evolutionary views of a variety of Christians at secular universities, including professors, graduate students, and pre-service teachers. Three studies investigated the perspectives of Christian students who attended secular universities: Brem, Ranney, and Schindel (2003), Dagher and BouJaoude (1997), and Hokayem and BouJaoude (2008). The latter two were naturalistic inquiry studies that explored views of Christian and Muslim biology majors in Lebanon. This study contributes to the research literature by showing 
how Christian biology-related majors at a Christian university in the United States viewed evolution and the processes by which those students came to accept evolution.

\section{Comparison of Results to Other Studies}

This study's findings contrast with other studies that explored university students' attitudes on evolution. Dagher and BouJaoude (1997) studied Lebanese Christian and Muslim biology majors and reported that several students rejected evolution solely on the basis of their religious beliefs. For some, perceptions of evolutionary theory as a purely mechanistic philosophy and of evolution as brutal survival of the fittest were antithetical to their religious worldview. Dagher and BouJaoude note, "For these students, the theory of evolution not only challenges their account for creation but violates an image of the world their beliefs and values afford them" (p. 440). Brem et al. (2003) conducted a survey of 135 public university students' perceived implications of evolution. Fifty-six percent of the study participants were Christian, and at least half of these were currently active in their religious beliefs. Sixty-seven percent of the participants were non-science majors. Brem et al. report that participants' perceptions [of evolution] were "overwhelmingly negative," and included a decrease in a sense of purpose, regardless of religious affiliation or non-belief.

In this study, only one of the fifteen participants rejected evolution. David, Participant 15, vigorously defended creationism and denounced evolution for what he perceived as its moral debasement and corrupting influence on societal values. In contrast, 14 participants did not attach negative implications to evolutionary theory. They supported evolution as a practical mechanism for the inception of new species and rejected any association with a negative view of competition for survival. The Discussion Supplement contains additional information regarding participants' views on the theological implications of evolution and is available as supplementary material accompanying the online article.

Relevance for University Professors

University professors may find this study as relevant in better understanding the factors in some Christian students' opposition to 
evolution and the transitions those students may experience in seeking to reconcile evolution and their personal religious beliefs. However, several factors may moderate the applicability and transferability of the findings of this study which focused entirely on the perspectives of biology-related majors and recent graduates from a Christian university. The Origins course professor and classroom environment through which many participants in this study came to terms with evolution may be more attuned to a Christian university setting than the secular university milieu. A variety of religions may be represented in a classroom at other universities. Secular university professors must judge whether it is appropriate to address Christian concerns about evolution in the classroom. The unique aspects of this study at a Christian university condition the appropriateness and transferability to other university settings.

Many professors at a secular university may be disinclined to discuss religion with students personally or within a classroom environment. For those university professors who choose to approach religious issues either personally or in a more public forum with students opposed to evolution for religious reasons, this study underscores the importance of helping students demarcate the domains of science and religion as they wrestle with the veracity of knowledge claims in those areas. The findings of this study may also assist those university professors with helping students recognize that being a Christian does not have to preclude an acceptance of evolution. These points of relevance are further discussed below.

An understanding of the unique ways in which science and religion construct knowledge is a universal necessity for scientifically literate citizens (National Academy of Sciences, 2008). The research literature is replete with studies that reinforce the importance of understanding the nature of science as a unique way of knowing (e.g., Bybee, 2004; Dagher \& BouJaoude, 1997). For those university professors who choose to broach religious issues with their students, a point of relevance is to address the nature of religion in addition to the nature of science as a means to better understand their respective domains. Discussion of belief versus acceptance of evolution would be apropos in this context (Williams, 2009). The Origins professor in this study did not explicitly address nature of science issues and did not make any distinction between belief and acceptance during class interactions. However, John, Participant 12, mentioned that a significant 
turning point for him occurred in a science education course when he learned to "really understand the true nature of science and how. . . [you] interpret evidence. . . That it's not just, 'Okay this is what we believe,' that there aren't beliefs in science and that there's just evidence and you either accept it or you don't."

The participants in this study who demonstrated the most nuanced understanding and unqualified acceptance of evolution were those 13 who engaged science and religion as non-overlapping domains. While a separation of science and religion may appear synonymous with non-interactive compartmentalization, most participants did not isolate the two domains. For many participants, scientific findings merely reinforced their greater respect for God's creative abilities. Two participants completely collapsed the domains of science and religion. Three participants inserted God's direct interposition in areas of perceived scientific uncertainty such as abiogenesis and cellular evolution. These three participants intimated the least certitude regarding evolution and held qualified positions. Abiogenesis was not explicitly discussed in the Origins course that was observed as part of this study. However, participant's dialog during the interviews indicated that they were aware of the abiogenesis issue; either through anti-evolution literature or in what they read in the Origins course textbooks that presented a scientific understanding of abiogenesis. Many participants expressed concern over bio-chemical mechanisms that contained random processes to explain the emergence of life on earth and perceived this as a direct threat to God's role as Creator. Ironically, the randomness of genetic variation did not trouble most participants during the creationism-evolution interview, but contingency in abiogenesis appeared to be a stumbling block to many participants. However, proper science requires using a naturalistic processes rationale to explain the natural world (National Academy of Sciences, 2008).

Alters and Alters (2001) note that while some educators claim that "discussions of prebiotic events are simply not appropriate for studying the biological [italics in original] theory of evolution" ( $p$. 100), other educators favor the inclusion of abiogenesis as an integrated approach to science teaching. Alters and Alters (2001) also observe, "Americans hold numerous misconceptions about these topics [e.g., abiogenesis] that contribute to their rejection of evolution" ( $p$. 100). For many of the participants in this study, the consideration of 
abiogenesis (and cellular evolution) as a standalone scientific issue free from religious trespassing was not a perfunctory task. Therefore, university professors' inclusion of abiogenesis in the context of evolution education may yield fruitful results for students with religious beliefs to better delineate the domains of science and religion. Some university professors (e.g., Smith, 1994) read statements to their classes to draw clear distinctions between science and religion prior to learning about evolution. The study's findings reinforce the importance of such practices, including discussion of natural phenomena such as abiogenesis.

Another point of relevance for university professors interested in helping Christian creationist students in their classrooms come to accept evolution is the importance of Christian role models who reconcile evolution with their religious beliefs. Many Christian creationist students at secular and Christian universities could have the same confined perspective as the participants in this study who were surprised to learn that a Christian could accept evolution. A number of religious organizations have publicly stated support for evolution (see National Center for Science Education, 2002). While perhaps helpful in making Christian creationist students aware of religious groups that support evolution, this study's findings indicate the importance of the individual role model, personified in a Christian who is also a scientist. Public university professors who interact personally with Christian creationist students may elect to recommend books written by Christian scientists that include personal testimonies of viewing evolution from a positive Christian perspective. Potential books include those written by Falk (2004), Lamoureux (2009), and Miller (1999). Other prominent Christian scientists who have avowed the compatibility of religious beliefs and evolution in published books are Collins (2006) and Ayala (2007). Hokayem and BouJaoude (2008) similarly suggest introducing models of persons who have "successfully incorporated more than one worldview" (p. 413) such as science and religion to help students reflect on ways to reconcile conflict between the two.

\section{Relevance for Researchers}

A point of relevance for researchers is the complexity of competing influences and encumbrances for university students who, though initially opposed to evolutionary theory because of religious perspectives, 
are beginning to study the evidence and individually decipher for the first time whether evolution is valid and qualified to be integrated within their worldview. For participants in this study, accepting evolution was not a mechanical task of dispassionately analyzing evidence like a trained scientist (Smith, 1994). Instead, many participants faced pressure from their parents to decry evolution. All the participants that transitioned from creationism to an acceptance of evolution had to reorder their long-held perspectives on the literalness of Genesis and the requisite conditions of salvation. For many participants, an acceptance of evolution engendered besetting theological complications as discussed in the supplementary material accompanying the online article. Some of these impediments to accepting evolution have been addressed by researchers (Dagher \& BouJaoude, 1997) but additional research is warranted in contexts other than at a Christian university and in other religious traditions. These underlying yet powerful hindrances necessitate a better examination to enable science educators to assist students with anti-evolutionist religious notions to progress towards accepting evolution.

The complex nature of many participants' approach to evolution in this study was manifested in their adverse reactions to random processes in abiogenesis. Although there were minor examples of a few participants viewing random processes as highly improbable in this study, many more participants expressed reservations about how random processes might eliminate God's place in the universe. Adverse reaction to randomness was most apparent in the Evolution Attitudes Survey (Ingram \& Nelson, 2006). Survey Item 9 stated, "It is statistically impossible that life arose by chance." Many Christians decode words like "chance," "spontaneous," and "random" as anti-theistic as demonstrated by the many participants in this study who interpreted "arose by chance" to imply a direct challenge to the legitimacy of God. Ingram and Nelson (2006) do not discuss their reasoning in the construction of Survey Item 9. If their purpose was to assess students' acceptance of abiogenesis only, the statement may have some unintended negative implications perceived by Christian students. Of the 255 students in Ingram and Nelson's study, 32\% were undecided on Survey Item 9 in the post-course survey. In this study, $47 \%$ of the 15 participants were undecided. Ingram and Nelson acknowledge the possibility that "students interpret the survey statements differently than we do" (p. 18), which may indeed have occurred with Survey Item 
9. An interesting alternative would be to assess responses by Christians to a similar question without the cumbersome code words and stated in the affirmative: "Life arose on Earth by natural processes." Therefore, another point of relevance in this study suggests that researchers who investigate attitudes about evolution must be cautious in constructing survey items and questionnaires. Without the benefit of follow-up exploration afforded in semi-structured interviews, Christians' misinterpretations may jeopardize the validity of questions that are intended to be religiously neutral.

\section{Conclusions}

The findings of this study demonstrate that participants who accepted evolution did so after an extended journey of processing the scientific evidence for evolution, considering other Christians' reconciliation of evolution and personal religious beliefs, and negotiating their own assumptions about the literalness of Genesis and matters of salvation. Constructivist educators recognize that the minds of students who come into the science classroom to learn about evolution are not a tabula rasa. Accepting evolution for participants in this study was not a simple matter of considering the evidence. Instead, many participants had to reorder and sort through competing interests and religious conceptions in deciphering how evolution could fit within their worldview. The results of this study demonstrate that the religious conflict over evolution need not persist on a personal level - Christian biology-related majors at a Christian university were able to retain a belief in God and accept evolution, thus achieving a measure of reconciliation between evolution and their personal religious beliefs.

\section{References}

Alters, B.J., \& Alters, S.M. (2001). Defending evolution: A guide to the creation/ evolution controversy. Sudbury, MA: Jones and Bartlett.

Astin, A.W., Astin, H.S., Lindholm, J.A., Bryant, A.N., Calderon, S., \& Szelényi, K. (2005). The spiritual life of college students: A national study of college students' search for meaning and purpose. Los Angeles: Higher Education Research Institute. 
Ayala, F.J. (2007). Darwin's gift to science and religion. Washington, DC: Joseph Henry Press.

Behe, M.J. (1996). Darwin's black box: The biochemical challenge to evolution. New York: Free Press.

Bishop, B.A., \& Anderson, C.W. (1990). Student conceptions of natural selection and its role in evolution. Journal of Research in Science Teaching, 27(5), 415-428.

Brem, S.K., Ranney, M., \& Schindel, J. (2003). Perceived consequences of evolution: College students perceive negative personal and social impact in evolutionary theory. Science Education, 87(2), 181-206.

Bybee, R.W. (2004). Evolution and the nature of science. In R.W. Bybee (Ed.), Evolution in perspective (pp. 15-24). Arlington, VA: National Science Teachers Association Press.

Cobern, W.W. (1994). Point: Belief, understanding, and the teaching of evolution. Journal of Research in Science Teaching, 31(5), 583-590.

Colburn, A., \& Henriques, L. (2006). Clergy views on evolution, creationism, science, and religion. Journal of Research in Science Teaching, 43(4), 419-442.

Collins, F.S. (2006). The language of God: A scientist presents evidence for belief. New York: Free Press.

Creswell, J.W. (2003). Research design: Qualitative, quantitative, and mixed methods approaches. Thousand Oaks, CA: Sage.

Dagher, Z.R., \& BouJaoude, S. (1997). Scientific views and religious beliefs of college students: The case of biological evolution. Journal of Research in Science Teaching, 34(5), 429-445.

Demastes, S.S., Settlage, J., \& Good, R.G. (1995). Students' conceptual ecologies and the process of conceptual change in evolution. Science Education, 79(6), 637-666.

Dutch, S.I. (2002). Religion as belief versus religion as fact. Journal of Geoscience Education, 50(2), 137-144.

Ebenezer, J.V. (1996). Christian preservice teachers' practical arguments in a science curriculum and instruction course. Science Education, 8o(4), 437-456.

Evans, M.E., Spiegel, A.N., Gram, W., Frazier, B.N., Tare, M., Thompson, S., \& Diamond, J. (2010). A conceptual guide to natural history museum visitors' understanding of evolution. Journal of Research in Science Teaching, 47(3), 326-353.

Falk, D.R. (2004). Coming to peace with science: Bridging the worlds between faith and biology. Downers Grove, IL: InterVarsity Press.

Fowler, J.W. (1981). Stages of faith: The psychology of human development and the quest for meaning. San Francisco: HarperCollins.

Fowler, J.W., Streib, H., \& Keller, B. (2004). Manual for faith development research (3rd ed.). Atlanta, GA: Emory University, Center for Research in Faith and Moral Development.

Ham, K.A. (1987). The lie: Evolution. Colorado Springs, CO: Master Books. 
Henderson, S. J. (2003). The impact of student religion and college affiliation on student religiosity. Retrieved from ProQuest Digital Dissertations. (AAT 3122408).

Hokayem, H., \& BouJaoude, S. (2008). College students' perceptions of the theory of evolution. Journal of Research in Science Teaching, 45(4), 395-419.

Holden, C. (2006). Darwin's place on campus is secure-But not supreme. Science, 311, 769-771.

Hume, E. (2007). Monkey girl: Evolution, education, religions, and the battle for America's soul. New York: HarperCollins.

Ingram, E.L., \& Nelson, C.E. (2006). Relationship between achievement and students' acceptance of evolution or creation in an upper-level evolution course. Journal of Research in Science Teaching, 43(1), 7-24.

Jackson, D.F., Doster, E.C., Meadows, L., \& Wood, T. (1995). Hearts and minds in the science classroom: The education of a confirmed evolutionist. Journal of Research in Science Teaching, 32(6), 585-611.

John Paul II., (1996). Magisterium is concerned with question of evolution, for it involves conception of man. L'Osservatore Romano (English Ed), 44(3), 7.

Judd R. (1997). Origins: A brief journey into the beginnings of things (3rd ed.). Oklahoma City, OK: Author.

Kardong, K.V. (2005). An introduction to biological evolution. New York: McGraw-Hill.

Kitzmiller V. (2005). Dover Area School District, 400 F. Supp. $2 d 707$ (M.D. Pa. 2005).

Lamoureux, D.O. (2009). I love Jesus \& I accept evolution. Eugene, OR: Wipf and Stock.

Lord, T., \& Marino, S. (1993). How university students view the theory of evolution. Journal of College Science Teaching, 22(6), 353-357.

MacArthur, J. (2001). The battle for the beginning: The Bible on creation and the fall of Adam. Nashville, TN: W. Publishing Group.

McKeachie, W.J., Lin, Y.G., \& Strayer, J. (2002). Creationists vs. evolutionary beliefs: Effects on learning biology. American Biology Teacher, 64(3), 189-192.

Meadows, L., Doester, E., \& Jackson, D.F. (2000). Managing the conflict between evolution and religion. American Biology Teacher, 62(2), 102-107.

Merriam, S.B. (1998). Qualitative research and case study applications in education. San Francisco: Jossey-Bass.

Miller, K.B. (Eds.). (2003). Perspectives on an evolving creation. Grand Rapids, MI: Eerdmans.

Miller, K.R. (1999). Finding Darwin's God: A scientist's search for common ground between God and evolution. New York: Cliff Street Books.

Moore, R. (2005). Nature, vanity, and the teaching of evolution. Journal of College Science Teaching, 34(4), 8-11.

Morris, H.M. (1976). The Genesis record: A scientific and devotional commentary on the book of beginnings. Grand Rapids, MI: Baker Book House. 
Morris, J.D., (2000). Does the creation worldview help in time of grief?

[Electronic version]. Dr. John's Q\&A, 138. Retrieved July 15, 2006, from http:// www.icr.org/article/763.

Murphy, N. (2002). Religion and science: God, evolution and the soul. Kitchener, Ontario, Canada: Pandora Press.

National Academy of Sciences. (1998). Teaching about evolution and the nature of science. Washington, DC: National Academies Press.

National Academy of Sciences. (2008). Science, evolution, and creationism. Washington, DC: National Academies Press.

National Center for Science Education. (2002). Statements from religious organizations. Retrieved March 1, 2008, from http://www.ncseweb.org/ resources/articles/5025_statements_from_religious_orga_12_19_2002.asp

O'Leary, D. (2003). A Biblical critique of creationism. Journal of Geoscience Education, 51(3), 309-312. Pallen, M.J., \& Matzke, N.J. (2006). From the origin of species to the origin of bacterial flagella. Nature Reviews: Microbiology, 4(10), 784-790.

Patton, M.Q. (1990). Qualitative evaluation and research methods (2nd ed.). Newbury Park, CA: Sage.

Renner, J.W., \& Stafford, D.G. (1979). Teaching science in the elementary school (3rd ed.). New York: Harper \& Row.

Rutledge, M.L., \& Warden, M.A. (1999). The development and validation of the measure of acceptance of the theory of evolution instrument. School Science and Mathematics, 99(1), 13-18.

Scott, E.C. (2009). Evolution vs. creationism: An introduction (2nd ed.). Berkeley, CA: University of California Press.

Scharmann, L.C. (2005). A proactive strategy. American Biology Teacher, 67(1), 12-16.

Sinatra, G.M., Southerland, S.A., McConaughy, F., \& Demastes, J.W. (2003). Intentions and beliefs in students' understanding and acceptance of biological evolution. Journal of Research in Science Teaching, 40(5), 510-528.

Smith, M.U. (1994). Counterpoint: Belief, understanding, and the teaching of evolution. Journal of Research in Science Teaching, 31(5), 591-597. Sobel, D. (2000). Galileo's daughter: A historical memoir of science, faith and love. New York: Penguin Books.

Stake, R.E. (2000). Case studies. In N.K. Denzin \& Y.S. Lincoln (Eds.), Handbook of qualitative research (2nd ed., pp. 435-454). Thousand Oaks, CA: Sage.

Tennyson, A. (2000). In memoriam A.H.H. In A. Roberts (Ed.), Alfred Tennyson (pp. 203-292). New York: Oxford University Press. (Original work published 1850)

Verhey, S.D. (2005). The effect of engaging prior learning on student attitudes toward creationism and evolution. BioScience, 55(11), 996-1003.

Wandersee, J., Mintzes, J., \& Novak, J. (1994). Research on alternative conceptions in science. In D. Gabel (Ed.), Handbook of research on science teaching and learning (pp. 177-210). New York: Macmillan. 
Williams, J.D. (2009). Belief versus acceptance: Why do people not believe in evolution? BioEssays, 31(11), 1255-1262.

Winslow, M.W. (2008). Evolution and personal religious belief: Christian biologyrelated majors' search for reconciliation at a Christian university. PhD diss. Kansas State University, http://hdl.handle.net/2097/710 Retrieved from ProQuest Digital Dissertations. (AAT 3310836).

Wright, R.T. (2003). Biology through the eyes of faith (Rev Ed.). San Francisco: HarperCollins.

\section{Supplementary Index (files not included)}

\section{Interview_Protocol_S1.pdf}

Ten Sample Questions from the Faith Development Interview. (pdf, 1 page, 59 $\mathrm{KB})$.

Interview_Protocol_S2.pdf

Interview protocol for the Creationism/Evolution Interview. (pdf, 1 page, $63 \mathrm{~KB}$ )

\section{Results_Supplement.pdf}

Description of the Origins course and learning environment at the study site university. (pdf, 2 pages, $77 \mathrm{~KB}$ )

\section{Discussion_Supplement.pdf}

This discussion provides additional supportive background on university students' perceptions of theological and social implications of evolution and expands on study participants' reflections on those issues. (pdf, 7 pages, $95 \mathrm{~KB}$ ) 